\title{
Genetic characterization of 18 novel microsatellite loci in northern pike (Esox lucius L.)
}

\author{
Jun Wang ${ }^{1}$, Chenghui Wang ${ }^{1}$, Long Qian ${ }^{2}$, Yuqing Ma ${ }^{1}$, Xinxin Yang ${ }^{1}$, Zsigmond Jeney ${ }^{3}$ and Sifa $\mathrm{Li}^{1}$ \\ ${ }^{1}$ Key Laboratory of Aquatic Genetic Resources and Utilization, Ministry of Agriculture, \\ Shanghai Ocean University, Shanghai, China. \\ ${ }^{2}$ Fisheries Technology Extension Station, Xinjiang Production and Construction Corps, Urumqi, \\ Xinjiang, China. \\ ${ }^{3}$ Research Institute for Fisheries, Aquaculture and Irrigation, Szarvas, Hungary.
}

\begin{abstract}
The northern pike (Esox lucius L.), an important predatory freshwater species, is undergoing significant population decline. In this study, 18 novel polymorphic microsatellite loci were isolated and used for assessing genetic variation in the Chinese Ulungur and Hungarian Balaton populations of the species. The number of alleles ranged from 2 to 13 , observed heterozygosity from 0.154 to 0.920 and expected heterozygosity from 0.145 to 0.921 , thereby indicating the specific usefulness of these suites of markers for investigating genetic variability.
\end{abstract}

Key words: northern pike, microsatellite loci, genetic variability.

Received: March 3, 2010; Accepted: September 6, 2010.

The northern pike (Esox lucius L.) is a predatory freshwater fish with circumpolar distribution in the Northern Hemisphere above latitude 40 and up to the Arctic zone (Jacobsen et al., 2005; Lucentini et al., 2006). In China, this fish is encountered only in an upstream region of the Irtse (Eltrixhe) River drainage area, in the northern part of Xinjiang Province, where the Ulungur and Jili lakes, the two major habitats (Li, 1981; Ren et al., 2002), are located. In the 1960 's, more than 120 tons of this species were harvested in China, this accounting for $20 \%$ of the total fish production in this watershed. However, since the end of the 1960's, there has been a sharp decline, as a consequence of commercial overexploitation and environmental changes. In 1999, the total harvest was only 15 tons (Ren et al., 2002), finally dropping to 7.5 tons in 2006 (Huo et al., 2009). A similar drop-off has also been reported in other continental populations (Lorenzoni et al., 2002; Launey et al., 2003). Thus, it is urgently necessary to conduct genetic conservation and management programs on this species.

The investigation of genetic diversity, a crucial step in the implementation of conservation strategies for endangered species, is however, dependent on the availability of appropriate genetic molecular markers. So far about $25 E$. lucius-specific microsatellite markers have been developed (Miller and Kapuscinski, 1996; Miller and Kapuscinski,

Send correspondence to Chenghui Wang. Key Laboratory of Aquatic Genetic Resources and Utilization, Ministry of Agriculture, Shanghai Ocean University, 201306 Shanghai, China. E-mail: wangch@shou.edu.cn.
1997; Launey et al., 2003). Nevertheless, due to limitations in the numbers of alleles and the low degree of polymorphism for these markers, the study of genetic variability in the northern pike will require the use of a larger number of loci (Launey et al., 2003). Therefore, the aims were to (1) isolate further novel polymorphic microsatellite loci, and (2) evaluate the applicability of these loci in the assessment of genetic variability in this fish.

In 2004, specimens of three wild populations of the northern pike in China were collected from the lakes Ulungur $(n=26)$, Jili $(n=21)$ and Beitun-183 $(n=21)$. Simultaneously, 25 individuals, sampled from Lake Balaton in Hungary in 2003, were used as reference population. A small piece of the caudal fin in each sample was removed and then stored in $95 \%$ ethanol.

Genomic DNA was extracted using a standard phenol-chloroform method (Sambrook and Russell, 2001). The pooled genomic DNAs of 30 individuals from China and 10 from Hungary were digested with the restriction enzyme Sau3AI. Fragments of 400-1,000 bp were isolated and purified, and then ligated to short linkers (Micr-A: 5'-GAT CGT CGA CGG TAC CGA ATT CT-3', Micr-B: 5'-GTC AAG AAT TCG GTA CCG TCG AC-3'). Microsatellitecontaining fragments were selectively coupled with a biotin-labeled $(\mathrm{CA})_{15}$ probe. These fragments were then ligated into a $p M D 19-\mathrm{T}$ vector and used for transforming competent Escherichia coli DH5a cells. Positive clones were subsequently tested by polymerase chain reaction (PCR) using M13 universal primers and sequenced using 


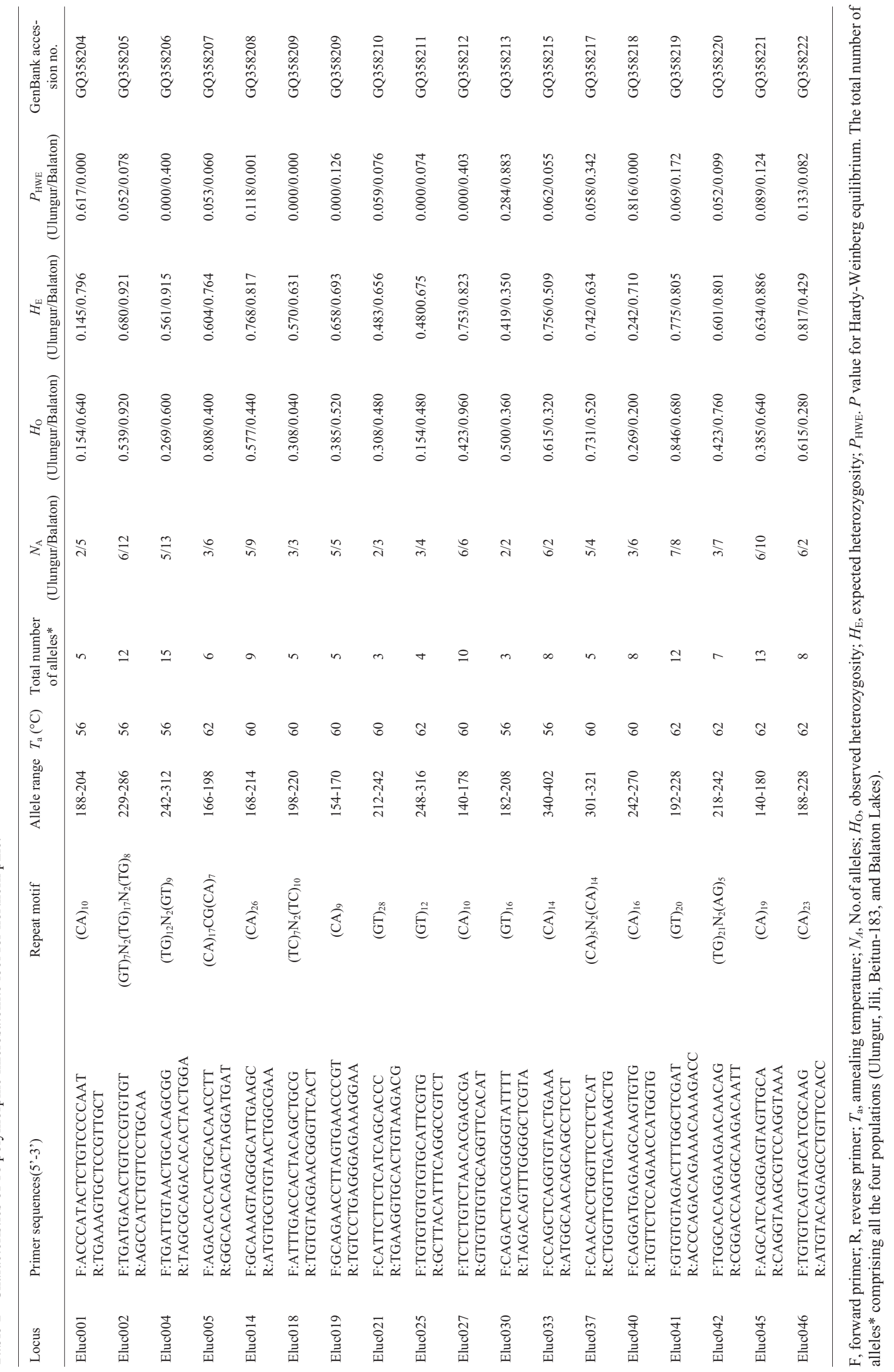


an ABI 3730 automatic sequencer (Applied Biosystems, USA). Specific PCR primers for the microsatellite loci were then designed, using the online software Web Primer.

PCR conditions were optimized by means of the AG-6321 gradient thermal cycler (Eppendorf, Hanburg, Germany), with an annealing step of $52-62{ }^{\circ} \mathrm{C}$ for selecting the optimum annealing temperature. The volume of each reaction mixture $(10 \mu \mathrm{L})$ was composed of $1 \mu \mathrm{L}$ of genomic DNA $(20 \mathrm{ng} / \mu \mathrm{L}), 5 \mu \mathrm{L}$ of buffer $(0.2 \mu \mathrm{M}$ dNTPs, $1.5 \mu \mathrm{M}$ $\mathrm{MgCl} 2,0.5 \mu \mathrm{M}$ Taq DNA polymerase), $1 \mu \mathrm{L}$ of primers $(0.5 \mu \mathrm{M}$ each) and $3 \mu \mathrm{L}$ of distilled water. The PCR conditions were as follows: initial denaturation for $5 \mathrm{~min}$ at $94{ }^{\circ} \mathrm{C}$, followed by 35 cycles for $30 \mathrm{~s}$ at $94^{\circ} \mathrm{C}, 30 \mathrm{~s}$ at optimal annealing temperature (Table 1 ), and $30 \mathrm{~s}$ at $72{ }^{\circ} \mathrm{C}$, followed by a terminal extension step of $10 \mathrm{~min}$ at $72{ }^{\circ} \mathrm{C}$. The PCR products were visualized by means of the QIAxcel multicapillary gel electrophoresis system (Qiagen, Hilden, Germany).

The observed heterozygosity $\left(H_{\mathrm{O}}\right)$, and expected heterozygosity $\left(H_{\mathrm{E}}\right)$ according to Nei's unbiased estimate (Nei, 1978) were calculated using POPGENE software (Yeh et al., 1999). FSTAT 2.9.4 software (Goudet, 1995) was used to test the linkage disequilibrium for all loci. Deviation from Hardy-Weinberg equilibrium (HWE) in each locus was estimated by using GENEPOP 3.4 software (Raymond and Rousset, 1995), and null alleles were detected with Micro-Checker (Van Oosterhout et al., 2004).

A total of 97 positive clones were selected for sequencing, of which 76 (78.4\%) contained microsatellite sequences (motifs repeated more than five times). From amongst these 76 clones, 48 microsatellite loci with adequate flanking regions were chosen to design primer pairs using the online software, which successfully generated PCR products. 18 primer pairs (Table 1) with a high degree of demonstrated polymorphism were used for population analysis. These 18 microsatellite loci were deposited in GenBank (accession no. GQ358204-GQ358222). Significant departure from HWE was evident in several loci in both populations (Table 1).

A total of 138 alleles were amplified by the 18 primer pairs in four populations. The mean number of alleles across loci and populations was 7.67. The values of observed and expected heterozygosities for each locus in the Ulungur and Balaton populations are presented in Table 1. In the Ulungur population, $H_{\mathrm{O}}$ ranged from 0.154 to 0.846 , and $H_{\mathrm{E}}$ from 0.145 to 0.817 , whereas in the Balaton population $H_{\mathrm{O}}$ ranged from 0.040 to 0.920 and $H_{\mathrm{E}}$ from 0.350 to 0.921 (Table 1). By means of the Micro-Checker software, six loci (Eluc004, Eluc014, Eluc018, Eluc019, Eluc027 and Eluc045) were detected to have a null allele in the two populations. There was no evidence of large allele dropout in any of the loci.

Investigating and detecting genetic diversity in northern pike hinges on both the availability of molecular markers and their implication. In the present study, 18 loci were detected as polymorphic, with relatively high numbers of alleles in the two populations tested. Some loci were found to have deviated from HWE in the two populations, which could have resulted from the presence of a null allele or the dramatic population decline in China (e.g., the total harvest in 2006 was only $6.25 \%$ of that in the 1960 s). There was no significant linkage disequilibrium in loci combinations following sequential Bonferroni correction for multiple tests. In conclusion, the results on genetic variability in the two populations analyzed herein indicate that these suites of markers are useful for investigating genetic diversity in the northern pike.

\section{Acknowledgments}

The authors are grateful to Mr. Jianguo Yin for his help in collecting the fish samples. This work was supported by the Xinjiang Production and Construction Corps Project (grant no. 2006GG18) and the Shanghai Leading Academic Discipline Project (grant no. Y1101).

\section{References}

Goudet J (1995) FSTAT, v. 1.2: A computer program to calculate $F$-statistics. J Hered 86:485-486.

Huo TB, Ma B, Tang FJ, Li Z, Jiang ZF, Cai LG, Adakbek KJ and Liu LZ (2009) Growth models and life-history pattern of Esox lucius in Ertixhe River. J Fish Sci China 16:316-322.

Jacobsen BH, Hansen MM and Loeschcke V (2005) Microsatellite DNA analysis of northern pike (Esox lucius L.) populations: Insights into the genetic structure and demographic history of a genetically depauperate species. Biol J Linn Soc 84:91-101.

Launey S, Krieg F, Morin J and Laroche J (2003) Five new microsatellite markers for Northern pike (Esox lucius). Mol Ecol Notes 3:366-368.

Li SZ (1981) Studies On Zoogeographical Divisions for Freshwater Fishes in China. 1st edition. Science Press, Beijing, $292 \mathrm{pp}$.

Lorenzoni M, Corboli M, Dörr AJM, Mearelli M and Giovinazzo G (2002) The growth of pike (Esox lucius Linnaeus, 1798) in Lake Trasimeno (Umbria, Italy). Fish Res 59:239-246.

Lucentini L, Palomba A, Lancioni H, Gigharelli L, Natali M and Panara F (2006) Microsatellite polymorphism in Italian populations of northern pike (Esox lucius L.). Fish Res 80:251262.

Miller LM and Kapuscinski AR (1996) Microsatellite DNA markers reveal new levels of genetic variation in northern pike. Am Fish Soc 125:971-977.

Miller LM and Kapuscinski AR (1997) Historical analysis of genetic variation reveals low effective population size in a northern pike (Esox lucius) population. Genetics 147:12491258.

Nei M (1978) Estimation of average heterozygosity and genetic distance from a small number of individuals. Genetics 89:583-590.

Raymond M and Rousset F (1995) GENEPOP v. 1.2: Population genetics software for exact tests and ecumenicism. J Hered $86: 248-249$ 
Ren ML, Guo Y, Zhang RM, Cai GL and Li H (2002) Fisheries Resources and Fishery of the Ertixhe River in China. 1st editon. Xinjiang Science, Technology and Sanitation Press, Urumqi, $226 \mathrm{pp}$.

Sambrook J and Russell DW (2001) Molecular Cloning: A Laboratory Manual. 3rd edition. Cold Spring Harbor Laboratory Press, New York, 483 pp.

Van Oosterhout C, Hutchinson WF, Wills DPM and Shipley P (2004) Micro-checker: Software for identifying and correcting genotyping errors in microsatellite data. Mol Ecol Notes 4:535-538.

\section{Internet Resources}

Yeh F, Boyle T, Rongcai Y, Ye Z and Xian J (1999) POPGENE v. 1.32, http://www.ualberta.ca/-fyeh/fyeh (November 2009).

Online Web Primer,

http://www.yeastgenome.org/cgi-bin/web-primer (November, 2009).

Associate Editor: Louis Bernard Klaczko

License information: This is an open-access article distributed under the terms of the Creative Commons Attribution License, which permits unrestricted use, distribution, and reproduction in any medium, provided the original work is properly cited. 